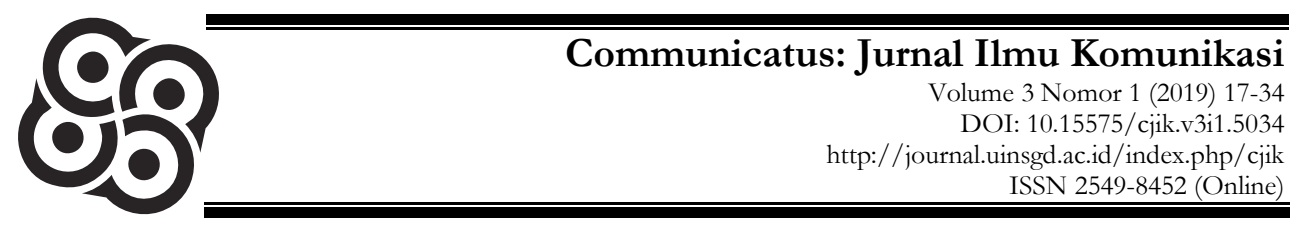

\title{
Intoleransi Keagamaan dalam Framing Surat Kabar Kompas
}

\author{
Enjang Muhaemin ${ }^{1}$, Irfan Sanusi ${ }^{2}$ \\ 12UIN Sunan Gunung Djati Bandung; \\ email.enjang.mubaemin@uinsgd.ac.id
}

\begin{abstract}
Indonesia is known as a multi-religious country in which there are various religions. United in diversity, and harmony in diversity becomes a key word that can no longer be contested. The intolerant attitude of any religious group can be a trigger for conflict which endangerthe integrity of the NKRI. This study aims to determine the framing of the Kompas newspaper in discussing and packaging the discourse of religious intolerance and religiosity in Indonesia. This research method uses Robert N. Entman's framing analysis, which focuses the study on the prominence of the framework of thought, perspective, concepts, and claims of media interpretation in interpreting the object of discourse. Research is expected to be able to stimulate the public to be more critical in understanding the various news constructed by journalists. The results showed that Kompas defined the problem of religious intolerance and diversity in Indonesia as a matter of religion, social, political, educational, and nationalism. However, Kompas generally defines it as a matter of understanding religion and weakening the attitude of nationalism. Kompas news considers the source of the cause to be more dominant because of superficial, partial, and little religious understanding. Kompas concludes that intolerance is a serious threat that could endanger the NKRI. The recommendations offered include the government being demanded to be assertive, fast, and not political. Religious leaders are recommended to build dialogical communication in an intense and continuous manner, and educate the public to always raise awareness of deep, moderate, and not extreme religiosity.
\end{abstract}

Keywords: Framing; Intolerance; Kompas

\begin{abstract}
ABSTRAK
Indonesia dikenal sebagai negara multiagama yang di dalamnya terdapat beragam agama. Bersatu dalam keragaman, dan harmoni dalam perbedaan menjadi kata kunci yang tak bisa lagi diganggu gugat. Sikap intoleran dari kelompok penganut agama manapun bisa menjadi pemicu konflik yang membahayakan keutuhan NKRI. Penelitian ini tujuan mengetahui pembingkaian surat kabar Kompas dalam mengupas dan mengemas wacana intoleransi keagamaan dan keberagamaan di Indonesia. Metode penelitian ini menggunakan analisis framing Robert N. Entman, yang memokuskan kajian pada penonjolam kerangka pemikiran, perspektif, konsep, dan klaim penafsiran

Diterima: Januari 2019. Disetujui: Maret 2019. Dipublikasikan: Juni 2019

17
\end{abstract}


Irfan Sanusi dan Enjang Muhaemin

media dalam memaknai objek wacana. Penelitian diharapkan mampu menstimuli masyarakat untuk kian kritis dalam memahami beragam berita yang dikonstruksi wartawan. Hasil penelitian menunjukkan, Kompas mendefinikan masalah intoleransi keagamaan dan keberagamaan di Indonesia sebagai masalah agama, sosial, politik, pendidikan, dan nasionalisme. Namun Kompas umumnya lebih mendefinisikan sebagai masalah pemahaman agama dan melemahnya sikap nasionalisme. Berita-berita Kompas menganggap sumber penyebabnya lebih dominan karena pemahaman agama yang dangkal, parsial, dan tidak mendalam. Kompas menyimpulkan intoleransi merupakan ancaman serius yang bisa membahayakan NKRI. Rekomendasi yang ditawarkan di antaranya pemerintah dituntut tegas, cepat, dan tidak berbau politis. Para tokoh agama direkomendasikan membangun komunikasi dialogis secara intens dan kontinyu, dan mendidik masyarakat untuk selalu meningkatkan kesadaran keberagamaan yang mendalam, moderat, dan tidak ekstrem.

Kata kunci : Framing; Intoleransi; Kompas

\section{PENDAHULUAN}

Indonesia bukan hanya dikenal sebagai negara multikultur yang memiliki beragam suku dan budaya, tapi juga disebut negara multiagama yang di dalamnya terdapat beragam agama. Bukan hanya Islam, Kristen Protestan, Kristen Katolik, dan Budha, tapi juga Hindu. Semboyan khas "Bhineka Tunggal Ika" yang kita miliki telah menyatukan bangsa Indonesia dalam satu kesatuan yang utuh dengan satu ikatan bernama Negara Kesatuan Republik Indonesia (NKRI). Bersatu dalam keragaman, dan harmoni dalam perbedaan, karenanya menjadi kata kunci yang tak bisa diganggu gugat. Dalam pandangan meurut Alpijar (2015), sikap saling menghargai antar-pemeluk agama merupakan jalan terbaik dalam kerangka melahirkan keharmonisan hidup beragama).

Toleransi dalam keberagamaan memiliki posisi dan peran penting dalam menjaga keutuhan bangsa dan negara. Sikap intoleran dari kelompok penganut agama manapun bisa menjadi pemicu konflik yang membahayakan keutuhan NKRI. Berpuluh tahun Indonesia hidup dalam suasana yang sejuk dan damai. Sikap intoleransi, dan tindakan radikal berbau agama, nyaris tak terlihat. Kalau pun ada, hanya sebatas dinamika kecil keagamaan dan keberagamaan yang tak sulit didamaikan dan diselesaikan. Agama bukan hanya dipahami sebagai sumber inspirasi, dan motivasi hidup, tapi juga menjadi sumber energi pembangun kebersamaan, dan penumbuh kasih sayang antarsesama.

Di Indonesia, sikap hidup keagamaan dan keberagamaan seperti di atas tampak terlihat jelas selama ini. Namun belakangan, wajah agama seolah berubah menjadi sesuatu yang menakutkan. Agama terkadang bukan hanya ditarik demi kepentingan politik pragmatis, tapi juga mulai dikonfrontasikan satu dengan lainnya. Intoleransi beragama dan keberagamaan mulai muncul di sana-sini, sehingga suasana yang awalnya damai dan sejuk berubah seketika.

Sikap toleransi antarpenganut agama yang selama ini terbangun seolah 
lenyap ditelan bumi, berganti dengan sikap intoleransi yang penuh curiga dan saling menyalahkan. Klaim paling benar menjadi pemandangan rutin yang kian kental, seakan nyaris sulit dan kian rumit untuk diselesaikan. Menurut Misrawi (2012), pluralitas agama, suku, budaya, dan bahasa di Indonesia memunculkan kekhawatiran banyak kalangan, terutama terkait maraknya intoleransi, dan kekerasan

Fenomena intoleransi dan konflik bernuansa agama di Indonesia seakan menguatkan kecurigaan bahwa agama sebagai penyebab konflik, pemicu tindak kekerasan, dan beragam perilaku yang terkadang bukan sekadar melahirkan kebencian, tapi juga permusuhan, dan peperangan dahsyat di antara sesama manusia. Menurut Kimball (2013:1), sejarah menujukkan bahwa cinta kasih, pengorbanan, dan pengabdian kepada orang lain sering kali berakar pada pandangan dunia keagamaan. Pada saat bersamaan, sejarah menunjukkan realitas agama yang dikaitkan langsung dengan contoh terburuk sikap dan tindakan manusia. Tak aneh bila kemudian agama di dunia dinilai sebagai sesuatu yang paradoks.

Sejarah manusia bagai tak pernah sepi dari konflik, baik dari konflik suku maupun konflik agama (Yunus, 2014). Berdasarkan data wawancara, diketahui bahwa persoalan clash antarumat beragama umumnya terjadi di tingkat akar rumput. Hal ini memperkuat dugaan adanya keterkaitan antara ranah ekonomi dan ranah agama atau relasi dalam ranah ekonomi memengaruhi relasi dalam ranah agama (Pamungkas : 2014).

Penelitian terkait intoleransi pernah dilakukan Imron Rosidi, Sholihul Huda, Moh. Toriqul Chaer, M. Fikri, dan Deni Miharja \& M. Mulyana. Rosidi (2016) dalam penelitian bertajuk "Muslim Saleh atau Radikal" yang memokuskan kajiannya pada prospek toleransi agama di Indonesia pasca-212 ini menyimpulkan, aksi bela Islam ini tidak mengancam toleransi beragama di Indonesia. Gerakan ini hanya akumulasi dari gejala menguatnya kesalehan publik masyarakat Islam. Radikalisme Islam sebagai sebuah gerakan yang membahayakan toleransi beragama di Indonesia sama sekali tidak nampak dalam aksi tersebut. Mayoritas peserta aksi secara murni dan tulus karena dorongan "kesalehan" untuk meminta keadilan hukum bagi sang "penista agama."

Penelitian Chaer (2012), berjudul "Tantularisme, Pluralitas Agama, dan Toleransi: Studi Kasus Masyarakat Ketanggi-Ngawi” menyimpulkan bahwa dialog intens antara agama dan budaya yang terjadi pada masyarakat Ketanggi dan masyarakat Jawa memposisikan agama dalam fungsinya sebagai landasan legal formal atas tradisi-tradisi budaya di masyarakat. Keadaan ini menimbulkan bias dan reduksi ajaran agama oleh selubung perilaku ritual-budaya masyarakat Ketanggi sebagai representasi masyarakat Jawa itu sendiri. Dialektika agama dan budaya pada masyarakat Ketanggi lebih condong pada penguatan legalitas budaya sebagai penggerak kesadaran kolektif bila dibandingkan dengan kekuatan 
Irfan Sanusi dan Enjang Muhaemin

moralitas sosial agama.

Dalam penelitiannya berjudul "Konflik Agama di Media Berita Online," Fikri yang melakukan kajian kritis terhadap pemberitaan Konflik Cikeusik pada portal Viva.co.id bulan Februari 2011 menyimpulkan bahwa massa penyerang dikonstruksi sebagai agresor yang brutal, sementara pihak korban dikonstruksi sebagai pihak yang mengalami trauma psikologis. Peneliti juga menyimpulkan bahwa model konflik yang diginakan adalah spiral konflik, dengan ciri lingkaran dinamis aksi, dan reaksi atau tindakan-tindakan purposif yang disengaja pihak agresor untuk menyerang pihak lain.

Sholihul Huda (2015) dalam penelitian "Kampung Inklusif: Model Toleransi Antar Agama di Balun Lamongan” menyimpulkan bahwa, faktor yang melatarbelakangi budaya toleransi di Balun adalah, faktor pemahaman agama masyarakat yang subtantif-inklusif, kebijakan politik yang pluralis, tradisi sosiokultur yang toleran, tradisi perkawinan beda agama yang terjaga. Intinya, paradigma masyarakat Balun dalam memahami ajaran agamanya (Islam, Hindu, Kristen) adalah paradigma subtantif-inklusif.

Miharja dan Mulyana (2019) dalam penelitian berjudul "Peran FKUB dalam "Menyelesaikan Konflik Keaagamaan di Jawa Barat" menyimpulkan, keberadaan FKUB adalah mutlak sebagai media merukunkan umat beragama, baik dalam melayani, sebagai jejaring aspirasi, dan menjembatani penyelesaian konflik antar umat beragama. Strategi penguatan terhadap FKUB bisa dilakukan melalui pendekatan soft power (sosialisasi) dan hard power (penegakan hukum dan peraturan).

Fenomena agama yang ditengarai sebagai kekuatan dahsyat, baik dalam mewujudkan perdamaian maupun permusuhan, menjadi kian menarik bila kemudian dikaitkan dengan pemberitaan media yang dianggap memiliki 'hak penuh' di dalam memilih dan mengonstruksi fakta, sekaligus sebagai pemilik kekuatan perkasa di dalam mempengaruhi opini publik. Jangan-jangan, sikap intoleran, dan kekerasan atas nama agama juga mendapat sumbangsih besar media melalui penentuan angle dan pembingkaian fakta dalam beragam pemberitaan selama ini.

Konflik atau pertentangan, terlebih konflik keagamaan selalu memiliki nilai berita. Dono Darsono dan Enjang Muhaemin (2012 : 30) menegaskan, konflik antara satu pihak dengan pihak lainnya selalu menarik wartawan untuk mengangkat pena, menulis berita. Dalam pandangan Sudibyo (2009 : 54-55), tatkala wartawan menulis berita, posisinya bukan hanya sebagai penjelas, tetapi juga melakukan proses konstruksi peristiwa dan realitas yang dilihat dan diamatinya.

Penulis tertarik mengkaji lebih dalam "Intoleransi Keberagamaan di Indonesia" dengan menggunakan analisis framing Robert N. Entman atas beritaberita Kompas, edisi April dan Mei 2017. Penelitian bertujuan mengetahui framing 
Kompas dalam baik dalam mendefinisikan masalah, memahami sumber masalah, keputusan moral, dan rekomendasi Kompas dalam menyelesaikan masalah intoleransi keagamaan dan keberagamaan di Indonesia. Memilih Kompas, karena beberapa pertimbangan.

Pertama, Kompas dianggap sebagai representasi surat kabar yang memiliki reputasi baik dalam dunia persuratkabaran di Indonesia. Kedua, memiliki kekhasan baik dari sisi sejarah (historis), maupun dari sisi segmentasi dan distribusi. Kompas dianggap sebagai surat kabar nasional yang mampu menembus pasar lokal di berbagai daerah. Perbedaan latar historis juga menjadi alasan dan pertimbangan peneliti untuk menjadikan media ini sebagai objek penelitian.

Penelitian ini menggunakan metode analisis framing Robert N. Entman. Data utama bersumber dari pemberitaan Kompas terkait pemberitaan intoleransi keagamaan dan keberagamaan di Indonesia, edisi April dan Mei 2017. Untuk memperkuat data, rujukan, dan analisis, penulis juga melakukan pengumpulan berbagai tulisan dari berbagai media cetak, buku, dan jurnal ilmiah.

Dalam kacamata pengkaji komunikasi, analisis framing umumnya digunakan untuk membedah cara-cara atau ideologi media di dalam mengonstruksi fakta atau realitas. Tak hanya itu, framing juga dipakai untuk melihat tentang bagaimana media memahami dan membingkai peristiwa (Eriyanto, 2009 : 10). Framing media dapat dimaknai sebagai cara bagaimana media menyajikan peristiwa, baik dilihat dari cara media menekankan bagian tertentu atau aspek tertentu suatu peristiwa, dan bagaimana cara media bercerita atas suatu realitas.

Di tataran teknis, framing yang dikemas media atas sebuah peristiwa atau pun fenomena dilakukan wartawan dengan melakukan penyeleksian isu tertentu dan melakukan pengabaian isu lain. Media juga menonjolkan sisi isu tertentu dengan. Kata penonjolan (salience) dimaknai dan didefinisikan sebagai proses di dalam membuat sebuah informasi untuk lebih diperhatikan, bermakna, dan berkesan (Sobur, 2009 : 164). Framing merujuk pada pemberian definisi, penjelasan, evaluasi, dan rekomendasi suatu wacana untuk menekankan kerangka pikir tertentu terhadap peristiwa yang diwacanakan (Siahaan, 2001 : 81).

Model analisis framing Entman dalam penelitian ini difokuskan untuk mengetahui bagaimana pembingkaian yang dilakukan Kompas pada pemberitaan intoleransi keagamaan dan keberagamaan di Indonesia.

\section{HASIL DAN PEMBAHASAN}

Dalam telaah framing ini, penulis fokus melakukan analisis terhadap berita-berita Kompas yang mengangkat isu atau peristiwa terkait intoleransi agama yang terjadi di Indonesia. Selama dua bulan, Kompas memuat 32 berita, dengan rincian 9 
Irfan Sanusi dan Enjang Muhaemin

berita di bulan April, dan 23 berita di bulan Mei. Dari semua berita, peneliti memilih sampel sebanyak 15 berita. Rinciannya 8 berita di bulan April dan 7 berita di bulan Mei sebagaimana tercantum pada dua tabel di bawah ini:

Tabel 1. Sampel Berita Intoleransi Kompas Bulan April 2017

\begin{tabular}{|c|c|c|}
\hline No & \multicolumn{2}{|c|}{ BULAN APRIL } \\
\hline 1 & Para Ulama Inginkan Kedamaian & 5 April 2017 \\
\hline 2 & Intoleransi akibat Kurang Paham Agama & 6 April 2017 \\
\hline 3 & Mencuat Komitmen Mewujudkan Literasi Digital & 6 April 2017 \\
\hline 4 & Ulama Cerdas Makin Dibutuhkan & 8 April 2017 \\
\hline 5 & Menag: Kedepankan Pemahaman Moderat & 13 April 2017 \\
\hline 6 & Indonesia-Islam Tak Bisa Dipertentangkan & 19 April 2017 \\
\hline 7 & Generasi Muda Diajak Perkuat Kebinekaan & 22 April 2017 \\
\hline 8 & Kerukunan Antarumat Beragama Jadi Modal Bangsa & 25 April 2017 \\
\hline
\end{tabular}

Tabel 2. Sampel Berita Intoleransi Kompas Bulan Mei 2017

\begin{tabular}{|c|c|c|}
\hline No & \multicolumn{2}{|c|}{ BULAN MEI } \\
\hline 1 & Laboratorium Kerukunan Beragama & 2 Mei 2017 \\
\hline 2 & Semangat Kemajemukan Perlu Diperkuat Sejak Dini & 22 Mei 2017 \\
\hline 3 & Megawati: Keberagaman sebagai Karakter Bangsa & 26 Mei 2017 \\
\hline 4 & Pemerintah Luncurkan Pekan Pancasila & 27 Mei 2017 \\
\hline 5 & Pemerintah Diminta Satu Bahasa dalam Bersikap & 27 Mei 2017 \\
\hline 7 & Dukungan terhadap Antiradikalisme Kian Meluas & 29 Mei 2017 \\
\hline
\end{tabular}

Dalam menganalisis strategi pembingkaian Kompas, penulis menggunakan empat parameter Entman, yakni Define Problem (Pendefinisan Masalah), Diagnose Causes (Memperkirakan Penyebab Masalah), Make Moral Judgment (Membuat Keputusan Moral), dan Treatment Recommendation (Menekankan Penyelesaian).

\section{Pendefinisian Masalah}

Define Problem atau pendefinisan masalah dapat dimaknai sebagai pembingkaian dan penekanan media dalam memahami peristiwa yang terjadi atau masalah yang muncul ke permukaan. Intinya, bagaimana wartawan memahami peristiwa atau isu tersebut. Terkait define problem, Kompas mendefinisikan masalah intoleransi keagamaan dan keberagamaan di Indonesia, pertama sebagai masalah agama, baik terkait tingkat pemahaman, maupun kondisi sosial keagamaan. Kedua, sebagai masalah pendidikan. Ketiga, sebagai masalah bangsa, baik terkait sikap keberagaman, kebhinekaan, maupun kesadaran nasionalisme, dan keempat sebagai masalah politik.

Berita berjudul "Intoleransi akibat Kurang Paham Agama" memandang masalah intoleransi ini sebagai masalah agama, khususnya tingkat pemahaman keagamaan. Pemahaman yang tidak mendalam terhadap agama ini yang kemudian dinilai memicu sikap intoleran, saling mengafirkan, dan tindakan radikal. Pendefinisian ini terlihat pada kutipan berita berikut: "Intoleransi dalam 
Intoleransi Keagamaan dalam Framing Surat Kabar Kompas) kehidupan berbangsa akbir-akhir ini menunjukkan masib kurangnya pemahaman keagamaan sebagian masyarakat..." Hal serupa juga termaktub pada berita "Ulama Cerdas Makin Dibutubkan," dan berita "Menag: Kedepankan Pemahaman Moderat."

Pendefinisian masalah seperti itu juga muncul pada teks berita yang menegaskan bahwa gerakan keyakinan yang ekstrem atau radikal bermunculan akibat pemahaman agama yang minim, dan tidak moderat. Berita "Dukungan terhadap Antiradikalisme Kian Meluas," juga menunjukkan intoleransi sebagai masalah agama, khususnya terkait paham radikal yang mengatasnamakan agama.

Pendefinisian masalah intoleransi, sebagai masalah agama, khususnya terkait kondisi sosial keagamaan yang ditunjukkan dengan kian menipisnya sikap saling menghormati antarpemeluk agama. Berita "Kerukunan Antarumat Beragama Jadi Modal Bangsa." menegaskan, bahwa kerukunan beragama merupakan budaya bangsa Indonesia, sehingga sikap intoleransi dan radikalisme agama dinilai sebagai akibat kian menipisnya budaya saling menghormati antarsesama pemeluk agama. Seakan menguatkan pendefinisian sebelumnya, berita Kompas bertajuk "Laboratorium Kerukunan Beragama" juga memandang sebagai masalah sosial keagamaan dan rendahnya kebersamaan sebagian pemeluk agama.

Intoleransi keagamaan dan keberagamaan di Indonesia dalam framing Kompas juga didefinisikan sebagai masalah pendidikan. Baik terkait sistem pendidikan dinilai baru sebatas mengajarkan pengetahuan, dan pengakuan, belum sampai pada penghayatan dan pengalaman real di lapangan, maupun terkait kesadaran akan kebhinekaan. Berita Kompas berjudul "Mencuat Komitmen Mewujudkan Literasi Digital' melihat intoleransi sebagai masalah pendidikan, pun demikian berita berjudul "Generasi Muda Diajak Perkuat Kebhinekaan."

Sistem pendidikan, demikian tulis Kompas, baru sebatas mengajarkan pengakuan keberagamaan bangsa, belum sampai pada proses penghayatan yang lebih dalam, misalnya melibatkan mereka pada pengalaman real di lapangan. Mengutip Darraz, Kompas menegaskan, sekolab belum mendorong guru dan siswa benarbenar menghayati keberagaman dalam realitas dengan menceburkan diri hidup bersama-sama orang yang berbeda tanpa rasa curiga.

Intoleransi keagamaan juga didefinsikan sebagai masalah bangsa, khususnya terkait kesadaran kebhinekaan. Berita "Semangat Kemajemukan Perlu Diperkuat Sejak Dini" melihat masalah intoleransi sebagai masalah pendidikan dalam wujud keterkikisan semangat kebinekaan. Berikut kutipan beritanya, "Pembelajaran tentang kebinekaan di sekolah hendaknya diperdalam agar peserta didik memiliki pemahaman mendasar yang kukuh. Semangat kemajemukan dalam diri siswa diperk.kuat sejak dini agar terhindar dari prasangaka yang memecah persatuan bangsa.”

Kompas juga membingkai intoleransi keagamaan dan keberagamaan di Indonesia sebagai masalah bangsa. Masalah krusial yang bisa mengancam keutuhan bangsa. Pembingkaian ini muncul dalam beberapa berita. Dalam berita "Para Ulama Inginkan Kedamaian," Kompas memaparkan kedamaian dan harmoni 
Irfan Sanusi dan Enjang Muhaemin

keagamaan di Indonesia mulai terganggu. Dalam kutipannya, berita ini menyampaikan pernyataan perwakilan ulama, pimpinan pesantren, dan organisasi kemasyarakatan Islam seusai bertemu Presiden Joko Widodo, di Istana Merdeka, Jakarta Selasa (4/4). Syukron Makmun, Pemimpin Pondok Pesantren Daarul Rahman Jakarta, menurut Kompas, berharap persoalan bangsa ini dapat diselesaikan dengan adil dan berpijak pada kebenaran (Kompas, 5 April 2017).

Dalam berita "Pemerintah Luncurkan Pekan Pancasila," Kompas memandang masalah intoleransi agama sebagai masalah bangsa yang menjadi ancaman keutuhan berbangsa dan bernegara. Berita berjudul "Bangun Persaudaraan, Pemerintahan Diminta Satu Bahasa dalam Bersikap" juga menegaskan hal serupa. Rongrongan terhadap persatuan dan keutuhan bangsa tak bisa dibiarkan, perlu tindakan tegas untuk menyelesaikannya.

Pendefinisian sebagai masalah bangsa, khususnya sebagai rongrongan membahayakan bangsa dan kebhinekaan ini terlihat pada teks berita berikut: "Shinta Nuriyah menuturkn, semua elemen bangsa memiliki kewajiban untuk menjaga bangsa dan negara dari berbagai macam rongrongan yang bertujuan mengobrak-abrik persatuan Indonesia” (Kompas, 27 Mei 2017).

Tak hanya itu, Kompas juga mendefinisikan masalah intoleransi sebagai masalah politik. Dalam berita "Indonesia-Islam Tak Bisa Dipertentangkean," Kompas melihat masalah intoleransi sebagai masalah perbedaan sikap, pandangan, dan pilihan figur calon dalam pemilihan kepala daerah. Masalah perbedaan politik menjadi faktor penting sehingga sikap intoleransi keberagamaan dan keagamaan semakin menguat dalam kehidupan sosiologis politik masyarakat.

Pendefinisian masalah demikian terlihat ketika Kompas mengutip pendapat Salahuddin, bahwa keberagaman, adalab fenomena yang terjadi di Indonesia sejak merdeka. Untuk itu, masyarakat harus dapat memahami perbedaan-perbedaan pandangan, sikap, dan piliban masing-masing. Masalah tidak akan terjadi jika semua pibake menghormati proses Pilkada DKI Jakarta (Kompas, 19 April 2017).

\section{Penyebab Masalah}

Diagnose Causes atau memperkirakan penyebab masalah merupakan dari suatu peristiwa. Penyebab dalam konteks ini bisa berarti apa (what), bisa juga berarti siapa (who). Merujuk pada berita-berita yang ditelaah, penelitian ini menunjukkan sumber penyebab masalah intoleransi di Indonesia dibingkai Kompas ke dalam beberapa masalah.

Pertama, masalah pemahaman agama para pelaku intoleransi yang dinilai dangkal, parsial, radikal, dan tidak mendalam. Kedua, masalah kentalnya nuansa politik, baik terkait dengan pilkada, pemanfaatan agama untuk kepentingan politik, maupun terkait solusi pemerintah yang dalam menyelesaikan masalah lebih bernuansa politis dibanding pendekatan hukum yang jelas, tegas, dan berkeadilan.

Ketiga, dalam framing Kompas, sistem pendidikan juga dinilai menjadi salah 
satu sumber penyebab masalah intoleransi keagamaan dan keberagamaan di Indonesia. Sistem pendidikan baru sebatas mengajarkan pengetahuan dan pengakuan terkait keberagaman dan keberagamaan, belum mampu mengajarkan pengalaman real di lapangan. Faktor demikian diframing Kompas sebagai salah satu penyumbang masalah lahirnya sikap intoransi keagamaan di Indonesia.

Keempat, framing Kompas tentang sumber penyebab masalah intoleransi keagamaan di Indonesia disebabkan karena kian menipisnya rasa kebangsaan, kebhinekaan, dan rendahnya rasa nasionalisme. Data-data penguat bahwa Kompas memframing sumber penyebab masalah intoleransi keagamaan dan keberagamaan di Indonesia seperti itu, dapat disimak pada hasil penelitian penulis atas sampel berita Kompas edisi April dan Mei 2017.

Terkait sumber penyebab intoleransi sebagai masalah pemahaman agama para pelaku intoleransi yang dangkal, parsial, dan radikal dapat disimak pada kutipan berita berikut:

"Semakin dalam pemahaman keagamaan seseorang seharusnya memunculkan sikap yang moderat, toleran, dan progresif. Sebaliknya, semakin kurang pemahaman seseorang akan agama, semakin mudah bersikap intoleran, mengafirkan yang berbeda, dan menyalabkean orang lain." (Kompas, 13 April 2017)

Menurut Lukman, berbagai fenomena munculnya paham-paham yang ingin memaksakan kehendak dan pemikirannya sendiri dan mudab menyalabkan pibak lain yang berbeda harus disikapi serius. Apalagi, paham-paham itu tidak banya menyalabkan, tetapi juga telah mengafirkan pibak yang berbeda. (Kompas, 13 April 2017)

Kompas juga memperkirakan penyebab masalah intoleransi keagamaan di Indonesia sebagai akibat solusi pemerintah yang lebih bernuansa politis, dibanding pendekatan hukum yang adil. Tak hanya itu, kentalnya nuansa politis, baik terkait pilkada, maupun pemanfaatan agama untuk kepentingan politik sesaat juga diframing Kompas sebagai sumber penyebab masalah intoleransi keagamaan di Indonesia.

Tak hanya itu, Kompas pun memframing sistem pendidikan di Indonesia sebagai salah satu sumber penyebab masalah intoleransi di Indonesia, dapat dicermati pada beberapa berita yang menjadi sampel penelitian. Dalam konteks pendidikan ini, sumber masalah intoleransi muncul ketika masyarakat dinilai relatif kurang mendapat pendidikan dan literasi digital. Implikasinya peserta didik menjadi mudah terbawa arus radikalisme dan termakan isu-isu hoaks.

Menurut Ramya, kerja barengan ini berinisiatif memberikan pendidikan literasi digital agar dalam era teknologi informasi dan komunikasi masyarakat dapat menggunakan teknologi digital secara baik. Paling tidak mampu mengatasi dampak buruk, seperti hoaks dan isu-isu radikalisme. "Dengan kolaborasi kami berakses, kualitas, dan kesetaraan pendidikan.” ujar Najeela. (Kompas, 6 April 2017) 
Irfan Sanusi dan Enjang Muhaemin

Tak hanya itu, dalam konteks pendidikan sebagai sumber masalah intoleransi, Kompas juga memframing pembelajaran kebinekaan dan keberagaman di dunia pendidikan masih sekadar formalitas, belum menyentu aspek substansi.

Selama ini, hal itu dilakukan sekedar formalitas dan minim kereasi pembelajaran. "Banyak hal simbolik terjadi di sekolah yang seharusnya tak hanya dilihat secara formal, tetapi dilihat dalam kerangka membangun pemahaman mendasar para siswa tentang kebinekaan," kata anggota Akademik Ilmu Pengetabuan Indonesia, Yudi Latif, saat berdialog dengan peserta Sekolah Guru Kebhinekan (SKG) di Jakarta (Kompas, 22 Mei 2017)

Sumber penyebab masalah intoleransi keagamaan di Indonesia juga akibat kian menipisnya sikap toleran, berkurangnya rasa kebangsaan, rendahnya pemahaman kebhinekaan, dan tergerusnya rasa nasionalisme. Ketika membuka Pekan Kerukunan Nasional di Manado, Minggu (23/4), Wakil Presiden Jusul Kalla mengingatkan, kerukunan antarumat beragama adalah modal bangsa Indonesia untuk maju. Tak ada bangsa yang maju jika selalu mengedepankan perbedaan masyarakatnya.

Kalla memuji kehidupan beragama yang rukun antar umat di sulut. Misalnya ketika konflik di Ambon dan di foto beberapa waktu lalu Kota Manado menjadi pengungsian bagi umat muslim dan Nasrani Oleh karena itu Wapres kalah berharap perdamaian dan kedamaian terus berlanjut di provinsi berpenduduk 2,5 juta yang kini dibanjiri wisatawan mancanegara (Kompas, 2 Mei 2017).

Seruan tersebut berisi lima poin yang berkait dengan kondisi kebangsaan akbir-akbir ini. Pada poin pertama, para tokoh bangsa menyerukan semua elemen bangsa, khususnya pemerintah, untuk melakukan penyadaran tentang pentingnya persatuan dalam Indonesia yang bbineka serta mendudukan Pancasila sebagai kepribadian bangsa. (Kompas, 27 Mei 2017)

\section{Keputusan Moral}

Make Moral Judgment atau membuat keputusan moral merupakan elemen framing untuk membenarkan atau memberikan argumen pada pendefinisian masalah yang sudah dibuat. Ketika masalah sudah didefinisikan, penyebab masalah sudah ditentukan, dibutuhkan sebuah argumen yang kuat untuk mendukung gagasan tersebut. Intoleransi keagamaan dan keberagamaan di Indonesia dinilai akan sangat berbahaya bila tidak segera diselesaikan dengan cepat dan tegas. Bukan hanya mencidera nlai-nilai keberagaman dan harmoni antar-umat beragama, tetapi juga dinilai akan mengancam keutuhan Negara Kesatuan Republik Indonesia (NKRI).

Dalam konteks keputusan moral ini, dapat ditarik tarik benang merah bahwa intoleransi keagamaan dan keberagaan merupakan ancaman yang tidak bisa dianggap sebagai angin lalu, tetapi sebagai ancaman serius yang bisa 
Intoleransi Keagamaan dalam Framing Surat Kabar Kompas) membahayakan kerukunan beragama dan keutuhan bangsa. Putusan moral ini secara substansial terlihat di sebagian besar berita yang menjadi sampel penelitian. Beberapa di antaranya dapat terlihat pada kutipan berita berikut:

Lukman mengatakan, pemahaman moderat itu tidak hanya untuk bisa menghormati keberagaman, tetapi sekaligus juga akan melindungi dan mengayomi. Sebagai mayoritas, lanjut Lukman, umat Islam di Indonesia berada di barisan terdepan dan paling bertanggung jawab melindungi semua warga bangsa. "Karena kewajiban mayoritas yang besar itu adalah melindungi," katanya (Kompas, 13 April 2017).

Ibarat mata uang, Islam dan Indonesia adalah dua sisi yang tidak bisa dipisabkan sama sekali. Oleh karena itu, kelompok-kelompok yang berupaya dan merenggangkan Islam dengan Indonesia harus dilawan karena merusak persatuan dan keberagaman (Kompas, 19 April 2017).

Ma'ruf mengatakan, ulama juga tidak boleb hanya berdiam di pesantren. Ulama harus keluar karena umat membutubkan mereka. "Saat ini ada ulama, ada ulama sungguban. Ada juga orang yang diulamakan, tetapi sebenarnya bukan ulama. Dijadikan kiai, padahal tak pernah ikut pesantren. Banyak yang seperti itu," ucapnya (Kompas, 8 April 2017)

Berita lainnya juga menunjukkan putusan moral yang serupa. Berita "Para Ulama Inginkan Kedamaian," misalnya, mendudukkan disharmoni dan ketidakdamaian antarpemeluk agama sebagai hal penting diselesaikan dengan segera, mengingat negara kita adalah negara pluralistik. Kedamaian yang diharapkan bukan bersifat abu-abu dan sementara, tapi jelas, dan bersifat permanen.

Berita berjudul "Intoleransi akibat Kurang Paham Agama" juga serupa. Kompas mendudukkan pemahaman yang keagamaan yang kurang mendalam sebagai 'pihak' yang bersalah, yang mengakibatkan sikap keagamaan dan keberagamaan menjadi intoleran, paling benar sendiri, dan radikal. Hal serupa juga muncul pada berita berjudul "Laboratorium Kerukunan Beragama" yang mendudukkan intoleransi sebagai ancaman yang membahayakan.

Putusan moral yang dikemukakan berita Kompas berjudul "Mencuat Komitmen Mewujudkan Literasi Digital' mendudukkan literasi digital sebagai upaya membendung informasi hoaks dan beragam konten negatif, termasuk radikalisme dan intoleransi. Bingkai putusan moralnya, intoleransi dinilai sebagai ancaman, yang terjadi akibat rendahnya penguasaan literasi digital. Hal yang sama juga tersirat pada berita berjudul "Generasi Muda Diajak Perkuat Kebhinekaan" yang mendudukkan pentingnya penguasaan kemampuan digital dalam meningkatkan sikap toleran, dan menangkal konten-konten negatif yang kian berkembang.

Penguatan kembali budaya kerukunan. Berita berjudul "Kerukunan Antarumat Beragama Jadi Modal Bangsa" mendudukkan pentingnya kembali 
Irfan Sanusi dan Enjang Muhaemin

menguatkan budaya kerukunan keagamaan, dan pemahaman keagamaan yang saling menghormati. Bingkai putusan moral yang menyiratkan ada bahaya di balik intoleransi keagamaan. Berita berjudul "Megawati: Keberagamaan Sebagai Karakter Bangsa" mendudukkan pentingnya kesadaran jati diri sebagai bangsa yang bhineka di tengah percaturan politik global.

Putusan moral yang dikemukakan berita Kompas berjudul "Bangun Persaudaraan, Pemerintahan Diminta Satu Bahasa dalam Bersikap" mendudukkan pentingnya kesadaran atas kebhinekaan dalam berbangsa dan keragamaan dalam beraagama. Bingkai putusan moral intoleransi sebagai ancaman itu tersirat ketika Kompas mengemas dan mengutarakan fenomena tersebut pada kutipan teks berita berikut: "Kita harus bangkit kembali menyelamatkan bangsa ini untuk ratusan bahkan ribuan tahun yang akan datang. Oleh karena itu, kita tidak boleh diam, kita harus bersuara menyampaikan kepada pemerintah, politisi, dan siapa saja bahwa kita harus keluar dari situasi ini,'"katanya.

\section{Rekomendasi Penyelesaian}

Treatment Recommendation atau rekomendasi penyelesaian dipakai untuk menilai apa yang dikehendaki media. Jalan apa yang dipilih untuk menyelesaikan masalah. Penyelesaian ini sangat tergantung pada bagaimana peristiwa itu dilihat dan siapa yang dipandang sebagai penyebab masalah. Merujuk pada data berita yang diteliti, maka dapat dipaparkan bahwa rekomendasi yang ditawarkan Kompas untuk meredam fenomena intoleransi keagamaan dan keberagamaan di Indonesia, di antaranya yakni:

Pertama, Kompas merekomendasikan pemerintah untuk menyelesaikan kasus intoleransi dengan pendekatan hukum seadil-adilanya, dan tidak berbau politis. Rekomendasi penyelesaian ini, terlihat pada teks berita berikut:

Para ulama menginginkan kedamaian antar-umat beragama terwujud di Indonesia. Keinginan tersebut dapat terwujud dengan membangun sikap saling menghormati dan menghargai antar-pemeluk agama. Sejalan dengan itu, peran pemerintah diharapkan dengan menegak.kan hukum secara adil. (Kompas, 5 April 2017)

Tren meningkatkean radikalisme, intolerasi, dan paham-paham yang menggerus semangat kebangsaan perlu segara diatasi bersama. Namun, langkah tegas pemerintah mengatasinya sangat dibutubkean. (Kompas, 27 Mei 2017)

Kedua, Kompas merekomensikan para tokoh agama untuk membangun komunikasi dialogis antar-umat beragama secara intens dan kontinyu, dan mendidik masyarakat beragama untuk selalu meningkatkan kesadaran keberagamaan yang mendalam, moderat, dan tidak ekstrem. Rekomendasi penyelesaian ini terlihat pada dua aline di bawah ini: 
Dalam Hikmah Isra Miraj yang dibadiri sejumlah tokoh agama nasional dan pemerintah di Manado, mantan Ketua Umum Pimpinan Pusat Muhammadiyah Din Syamsuddin juga meyakini, dialog antarumat beragama yang dilakukan terusmenerus memiliki kekuatan membangun bangsa ini (Kompas, 25 April 2017)

"Dialog yang dialogis, transparan, dan terus terang menjadi kekuatan menyatukan bangsa ini dari rasaa curiga," katanya (Kompas, 25 April 2017).

"Di tengah kemajemukan, pluralitas, keragaman bangsa kita yang ada di hampir semua lini kebidupannya, saya tidak jemu mengingatkan diri saya dan kita semua agar senantiasa mengedepankan moderasi agama, pemahaman agama yang moderat. Moderat itu artinya lawan dari ekstrem," ujar Menag (Kompas, 13 April 2017).

Ketiga, rekomendasi penyelesaian yang ditawarkan Kompas adalah pentingnya tindakan ulama yang tidak memaksa orang, dan tidak melakukan teror. Rekomendasi lanjutannya mendorong masyarakat tidak ragu memasukkan anaknya ke pesantren. Ini dinilai penting, agar semakin banyak ulama yang dapat membimbing umat menjadi lebih baik. Rekomendasi ini terlihat pada dua alinea di bawah ini:

Dalam menjaga umat, ulama tidak boleh memaksa orang. Mereka juga tidak boleh melakukan teror. Ma'ruf mengatakan, teror bukanlah jihad. "Seperti pengeboman, itu bukanlah jihad, tetapi teror. Jangan pakai ancaman, intimidasi, babkan perang," ujarnya (Kompas, 8 April 2017).

Menurut Ma'ruf, kehidupan moderat di Indonesia saat ini salah satunya didorong pendidikan di pesantren sejak usia dini. "Santri dididik sejak kecil sehingga mereka menjadi individu yang akhlakul karimah (akblak mulia)," katanya (Kompas, 8 April 2017).

Keempat, Kompas merekomendasikan para pendidik untuk mampu memberikan pengalaman toleransi keagamaan dan keberagamaan secara lebih nyata, bukan sekadar konsep dan teorik semata. Rekomendasi ini terlihat pada dua alinea teks berita di bawah ini:

Cara lain melalui kegiatan praktis atau tindakan nyata. Jalan ini ditempub dengan para siswa dari berbagai latar belakang menggelar kegiatan di luar kelas, mulai dari berkemah, mengerjakan proyek sosial ke masyarakat, bingga kunjungan ke rumah ibadah semua agama (Kompas, 22 Mei 2017).

Kelima, Kompas merekomendasikan generasi muda untuk mendalami literasi media. Rekomendasi ini dianggap penting karena selain akan membentengi generasi muda dari beragam informasi hoaks, palsu, berbau hasutan, dan kebencian, juga dapat mendorong mereka untuk melakukan produksi konten-konten digital yang positif. Rekomendasi ini terlihat pada teks berita di bawah ini: 
Irfan Sanusi dan Enjang Muhaemin

Generasi muda dapat berperan memperkuat kebinekaan dan melawan fenomena radikalisme. Mereka perlu diberdayakan agar mampu menciptakan muatan positif yang tidak melupakan nilai keberagaman dan toleransi melalui media sosial (Kompas, 22 April 2017)

Realitas agama, baik itu berupa isu, peristiwa, fenomena, maupun pendapat sumber berita, bisa dikonstruksi secara berbeda, sekalipun semuanya itu--baik isu, peristiwa, fenomena, maupun pendapat sumber berita-berasal dari peristiwa atau sumber yang sama. Media, bagaimana pun, memiliki peran penting di dalam memilih dan menonjolkan aspek tertentu kepada khalayak yang menjadi sasarannya. Banyak faktor yang mempengaruhi sebuah realitas, peristiwa atau pun fenomena yang sama menjadi berbeda ketika dikonstruksi oleh wartawan yang berbeda, terlebih bila para wartawan itu berada di media yang berbeda pula. Teks ujaran, angle pemberitaan serta ilustrasi gambar berupa foto atau grafik yang mereproduksi peristiwa menjadi sebuah berita sangat dipengaruhi oleh ideologi media yang bersangkutan (Syuderajat, 2018).

Konstruksi yang berbeda, bisa jadi bukan hanya karena faktor ideologi, dan pertimbangan ekonomi, tapi juga bisa karena faktor-faktor lainnya, yang ikut andil di dalam membingkai suatu realitas dalam suatu media. Dalam konteks inilah, analisis framing menjadi penting untuk membedah konstruksi media atas sebuah realitas. Mengutip Entman, Sudibyo (2009: 157) menegaskan, prinsip analisis framing menyatakan bahwa terjadi proses seleksi dan penajaman terhadap dimensi-dimensi tertentu dari fakta-fata yang diberitakan media.

Masalah kehidupan beragama bukanlah persoalan ringan. Toleransi masih menjadi problem berat di tengah persaingan antar-agama menjalankan syariat dan memperbanyak pengikutnya. Kehidupan yang harmonis pun masih menjadi pertanyaan akan keterwujudannya (Rini Fidiyani, 2013). Kasus intoleransi keagamaan dan keberagamaan di Indonesia, merujuk pada hasil penelitian beritaberita yang dimuat surat kabar Kompas, dapat ditarik benang merah bahwa akar masalah berkembangnya intoleransi keagamaan dan keberagamaan di Indonesia tidaklah bersifat tunggal. Ada karena sikap pemerintah yang kurang cepat dan tegas dalam menangani kasus intoleransi, ada juga karena faktor politik, sosial, dan pemahamanan keagamaan yang masih bersifat parsial dan dangkal di sebagian masyarakat pemeluk agama.

Berdasarkan itulah, maka meredam dan melakukan penyelesaian kasus intoleransi di Indonesia menuntut banyak pihak terlibat, dengan beragam cara penyelesaian yang tepat. Setidaknya ada tiga hal penting yang layak mendapat perhatian. Pertama, pemerintah harus mampu membaca akar tumbuhnya intoleransi keagamaan dan keberagaaman secara komprehensif, bukan secara dangkal dan parsial. Ini mendesak agar solusi pencegahan dan penanggulangan intoleransi agama bisa optimal dan tuntas hingga ke menyentuh substansinya.

Pandangan ini sejalan pendapat Moh. Rosyid (2014 : 75), bahwa persoalan 
penting sebagai solusi adalah mencari akar persoalan yang menjadi pemicunya. Akar penyebab tumbuh berkembanganya radikalisme yang mengatasnamakan agama membutuhkan kajian yang mendalam dan komprehensif (Enjang Muhaemin, 2013, 84-85). Ini penting karena penyebabnya bisa karena banyak faktor, bukan hanya karena pemahaman agama yang dangkal, tetapi juga faktorfaktor lain

Kedua, para pengelola media -- diakui atau tidak -- memiliki peran strategis dalam mengungkap akar masalah tumbuh kembangnya radikalisme agama. Karenanya media diharapkan mampu mengungkapnya secara komprehensif, objektif, netral, dan tidak bias ideologis. Media agar dapat memosisikan diri sebagai sumber solusi dalam meredam tumbuhnya intoleransi keagamaan dan keberagamaan di Indonesia.

Ketiga, mengingat berbagai tokoh agama memiliki peran penting dalam membangun sikap toleransi beragama yang tepat, maka para pemuka agama diharapkan mampu membimbing mereka dalam berkeyakinan, bersikap, dan berperilaku yang lebih mendorong terwujudnya sikap saling menghormati dan menghargai satu sama lain, sehingga intoleransi keagamaan dan keberagamaan tidak kembali terjadi. Bahkan tak kalah pentingnya, para pemuka agama juga bukan hanya dituntut melakukan komunikasi dialogis satu sama lain, tetapi juga melakukan pendidikan dialogis yang terencana.

Dalam bukunya Islamic Education and Indoctrination: The Case in Indonesia (2011 : 134), Charlene Tan menganjurkan, untuk menanamkan pluralisme keberagamaan, penting adanya pendidikan dialogis (dialogical education). Pendidikan ini terdiri dari tiga macam: dialog persiapan (preliminary dialogue), contohnya dengan mengunjungi tempat ibadah agama lain, dialog praktis (practical dialogue) dengan bekerja sama antar-pemeluk umat beragama, dan dialog kritis (critical dialogue), yaitu dialog terencana antar-umat beragama.

\section{PENUTUP}

Merujuk pada hasil analisis berbasis framing ini, maka penelitian ini memberikan simpulan penting bahwa intoleransi keagamaan dan keberagamaan di Indonesia bukan muncul karena penyebab tunggal. Intoleransi lahir dari akar masalah yang beragam. Implikasinya, penyelesaian masalah intoleransi pun membutuhkan penyelesaian yang beragam dan menukik pada akar masalahnya.

Berpijak pada telaah yang penulis dilakukan, maka ada beberapa simpulan yang penting dikemukakan. Pertama, surat kabar Kompas mendefinisikan masalah intoleransi keagamaan dan keberagamaan di Indonesia sebagai masalah agama, sosial, politik, pendidikan, dan nasionalisme. Namun begitu, berita-berita surat kabar Kompas umumnya lebih mendefinisikan intoleransi keagamaan dan keberagamaan di Indonesia sebagai masalah agama dan nasionalisme.

Kedua, kendati intoleransi keagamaan dan keberagamaan di Indonesia 
Irfan Sanusi dan Enjang Muhaemin

didefinsikan sebagai masalah yang beragam, namun berita-berita Kompas menganggap yang menjadi sumber penyebab masalab intoleransi keagamaan lebih dominan karena aspek pemahaman agama para pelaku intoleransi yang dinilai dangkal, parsial, dan tidak mendalam. Kompas juga berpandangan bahwa intoleransi beragama dan keberagamaan yang terjadi di Indonesia disulut oleh kepentingan politik tertentu, dan rendahnya rasa nasionalisme yang dimiliki para pelaku intoleransi keagamaan dan keberagamaan di Indonesia.

Ketiga, intoleransi keagamaan dan keberagamaan di Indonesia dinilai akan sangat berbahaya, bila tidak segera diselesaikan dengan cepat dan tegas. Bukan hanya mencidera nlai-nilai keberagaman dan harmoni antar-umat beragama, tetapi juga dinilai akan mengancam keutuhan Negara Kesatuan Republik Indonesia (NKRI) yang berlandaskan pada Pancasila dan UUD 1945. Dalam konteks keputusan moral ini, intoleransi keagamaan dan keberagaan dinilai sebagai ancaman yang tidak bisa dianggap angin lalu, tetapi sebagai ancaman serius yang bisa membahayakan keutuhan NKRI.

Keempat, untuk meredam dan menyelesaikan kasus intoleransi keagamaan dan keberagamaan di Indonesia, Kompas merekomendasikan agar dilakukan secara komprehensift, berkelanjutan, dan melibatkan banyak pihak. Tak bisa hanya diselesaikan oleh pemerintah, dan tokoh agama, tetapi juga menuntut keterlibatan tokoh masyarakat, kalangan pendidik, dan generasi muda. Tanpa ini, maka kasus intoleransi bukan hanya sulit diredam, bahkan kondisinya bisa kian rumit dan membahayakan keutuhan bangsa dan negara.

\section{DAFTAR PUSTAKA}

Alpizar. (2015). Toleransi Terhadap Kebebasan Beragama di Indonesia (Perspektif Islam). Toleransi: Media Komunikasi Umat Bergama, 7(2).

Chaer, M. T. (2012). Tantularisme, Pluralitas Agama, dan Toleransi: Studi Kasus Masyarakat Ketanggi-Ngawi dalam Jurnal Afkearuna, 8(2).

Darsono, D. dan Muhaemin, E. (2012). Secangkir Peristiwa di Mata Wartawan. Bandung: Mimbar Pustaka.

Eriyanto. (2009). Analisis Framing, Konstruksi Ideologi, dan Politik Media. Yogyakarta: Lkis.

Eriyanto. (2009). (2009). Analisis Wacana, Pengantar Analisis Teks Media. Yogyakarta: LKiS.

Fidiyani, R. (2013). Kerkunan Umat Beragama di Indonesia (Belajar Keharomonisan dan Toleransi Umat Beragama di Desa Cikakak, Kec. Wangon, Kab. Banyumas) dalam Jurnal Dinamika Hukum, 13(3).

Fikri, M. (2012). Konflik Agama Dalam Media Berita Online (Kajian Kritis Pemberitaan Konflik Cikeusik dalam Portal VIVA.CO.ID Pada Periode Bulan Februari) dalam Jurnal Komunikasi dan Realitas Sosial, 4(4).

Huda, S. (2015). Kampung Inklusif: Model Toleransi Antar Agama di Balun 
Lamongan dalam Jurnal Al-Hikmah: Jurnal Studi Agama-Agama, 1(1).

Kimball, C. (2013). Kala Agama Jadi Bencana. Bandung: Mizan.

Miharja, D. dan Mulyana, M. (2019). Peran FKUB dalam Menyelesaikan Konflik

Keaagamaan di Jawa Barat dalam Religious dalam Jurnal Studi Agama-agama dan Lintas Budaya, 3(2).

Misrawi, Z. (2012). Kesadaran Multikultural dan Deradikalisasi Pendidikan Islam, Pengalaman Bhinneka Tunggal Ika dan Qabul Al-akhar dalam Jurnal Pendidikan Islam, 1(2).

Muhaemin, E. (2013). Agama dan Media di Era Informasi. Bandung: Mimbar Pustaka.

Pamungkas, C. (2014). Toleransi Beragama dalam Praktik Sosial: Studi Kasus Hubungan Mayoritas dan Minoritas Agama di Kabupaten Buleleng dalam Epistemé, 9(2)

Rosidi, I. (2016). Muslim Saleh atau Radikal: Prospek Toleransi Agama di Indonesia Pasca-212 dalam Jumal Toleransi: Media Komunikasi Umat Beragama, 8(2).

Rosyid, M. (2014). Keselarasan Hidup Beda Agama dan Aliran: Interaksi Nahdliyin, Kristiani, Buddhis, dan Ahmadi di Kudus dalam Jurnal Fikerah, 2(1).

Sobur, A. (2009). Analisis Teks Media: Suatu Pengantar Untuk Analisis Wacana, Analisis Semiotik, dan Analisis Framing. Bandung: PT. Remaja Rosdakarya.

Sudibyo, A. (2009). Politik Media dan Pertarungan Wacana. Yogyakarta: LKiS.

Syuderajat, F. (2018). Idiologi Surat kabar dalam Pemberitaan Terorisme. Communicatus: Jurnal Ilmu Komunikasi, 1(1), 1-12.

Tan, C. (2011). Islamic Education and Indoctrination: The Case in Indonesia. Routledge Research in Education

Yunus, F. M. (2014). Konflik Agama di Indonesia, Problem dan Solusi Pemecahannya dalam Jurnal Substantia, 16(2). 
Irfan Sanusi dan Enjang Muhaemin 